\title{
Anthropometric change: implications for office ergonomics
}

\author{
Claire C. Gordon, Ph.D ${ }^{\mathrm{a}}$ and Bruce Bradtmiller, Ph.D. ${ }^{\mathrm{b}}$ \\ ${ }^{a}$ US Army Natick Soldier Center, Natick, MA, 01760-5020 USA \\ b Anthrotech, 503 Xenia Avenue, Yellow Springs, OH, 45387 USA
}

\begin{abstract}
Well-designed office workspaces require good anthropometric data in order to accommodate variability in the worker population. The recent obesity epidemic carries with it a number of anthropometric changes that have significant impact on design. We examine anthropometric change among US civilians over the last 50 years, and then examine that change in a subset of the US population - the US military - as military data sets often have more ergonomic dimensions than civilian ones. The civilian mean stature increased throughout the period 1962 to 2006 for both males and females. However, the rate of increase in mean weight was considerably faster. As a result, the male obesity rate changed from $10.7 \%$ in 1962 to $31.3 \%$ in 2006. The female change for the same period was $15.8 \%$ to $33.2 \%$. In the Army, the proportion of obesity increased from $3.6 \%$ to $20.9 \%$, in males. In the absence of national US ergonomic data, we demonstrate one approach to tracking civilian change in these dimensions, applying military height/weight regression equations to the civilian population estimates. This approach is useful for population monitoring but is not suitable for establishing new design limits, as regression estimates likely underestimate the change at the ends of the distribution.
\end{abstract}

Keywords: anthropometry, secular trend, obesity, workspace design

\section{Introduction}

Well-designed office workspaces require good anthropometric data in order to accommodate variability in the worker population. Historically, anthropometric changes in human populations, at least in developed countries, were a function of gradual increases in body height, or stature - the secular trend. More recently, an obesity epidemic is becoming a worldwide phenomenon. This epidemic carries with it a number of anthropometric changes that have significant impact on the design of office workspaces. We examine anthropometric change among US civilians over the last 50 years, and then examine that change in a subset of the US population - the US military. We conclude by exploring the impact of those changes on the standards used by office furniture manufacturers to design their products.

\section{Method}

We examined national probability samples of US anthropometry from 1962 through 2006, using data from the National Health Examination Survey (1962)
[12] and the series of National Health and Nutrition Examination Surveys [7]. A 2007-2008 update of NHANES data has been released, but samples were smaller than in the 2003-2006 four-year cycle. We use the 2006 data here because the next four-year cycle sample, 2007-2010, has not yet been released. In addition to mean height and weight, we calculated obesity prevalence rates as a measure of population change. We followed the US Centers for Disease Control definition of obesity, which is a Body Mass Index (BMI) greater than 30. The BMI is calculated as weight (in $\mathrm{kg}$ )/stature (in meters) $)^{2}$.

Because few ergonomic dimensions are available in the US national probability samples, many designers and standards developers use US military data, where ergonomic dimensions are abundant. In order to examine military samples over a similar time period, we took data from US Army soldiers in measured in 1966 (6,682 males) [13], 1987-1988 (1774 males; 2208 females) [4] and again in 20062007 (2811 males; 651 females) [2, 5]. Obesity rates for these samples were calculated as well. 


\section{Results}

The civilian mean stature increased throughout the period 1962 to 2006 for both males and females. However, the rate of increase in mean weight was considerably faster (Figure 1).

As a result of body weight increasing more rapidly than stature, the male obesity rate changed from $10.7 \%$ in 1962 to $31.3 \%$ in 2006 . The female change for the same period was $15.8 \%$ to $33.2 \%$ (Table 1 ). In the Army, the proportion of obesity increased from $3.6 \%$ to $20.9 \%$, in males. We had insufficiently representative data to get reliable estimates for the females in the 2006-2007 study. Figures 2 and 3 show the increase in stature and weight, respectively, during the comparative time period for both US civilian males and US Army males. Table 2 shows the prevalence of obesity for these populations over the same time period.
Our most comparable military data sets are from 1987-1988 and 2006-2007. Examining those two data sets in particular, mean values increased for a number of important ergonomic dimensions in approximately 20 years (Table 3 ). For example, male biacromial (shoulder) breadth increased $12.7 \mathrm{~mm}$; male bideltoid (upper arm) breadth increased $8.1 \mathrm{~mm}$, while male torso circumferences - all important in personal protective equipment - increased $40 \mathrm{~mm}$ or more.

\section{Discussion}

Military populations are different from the civilian population in that the demographic distributions are different, it is not a random sample from the civilian population, and physical fitness requirements ensure that, in general, military populations are more
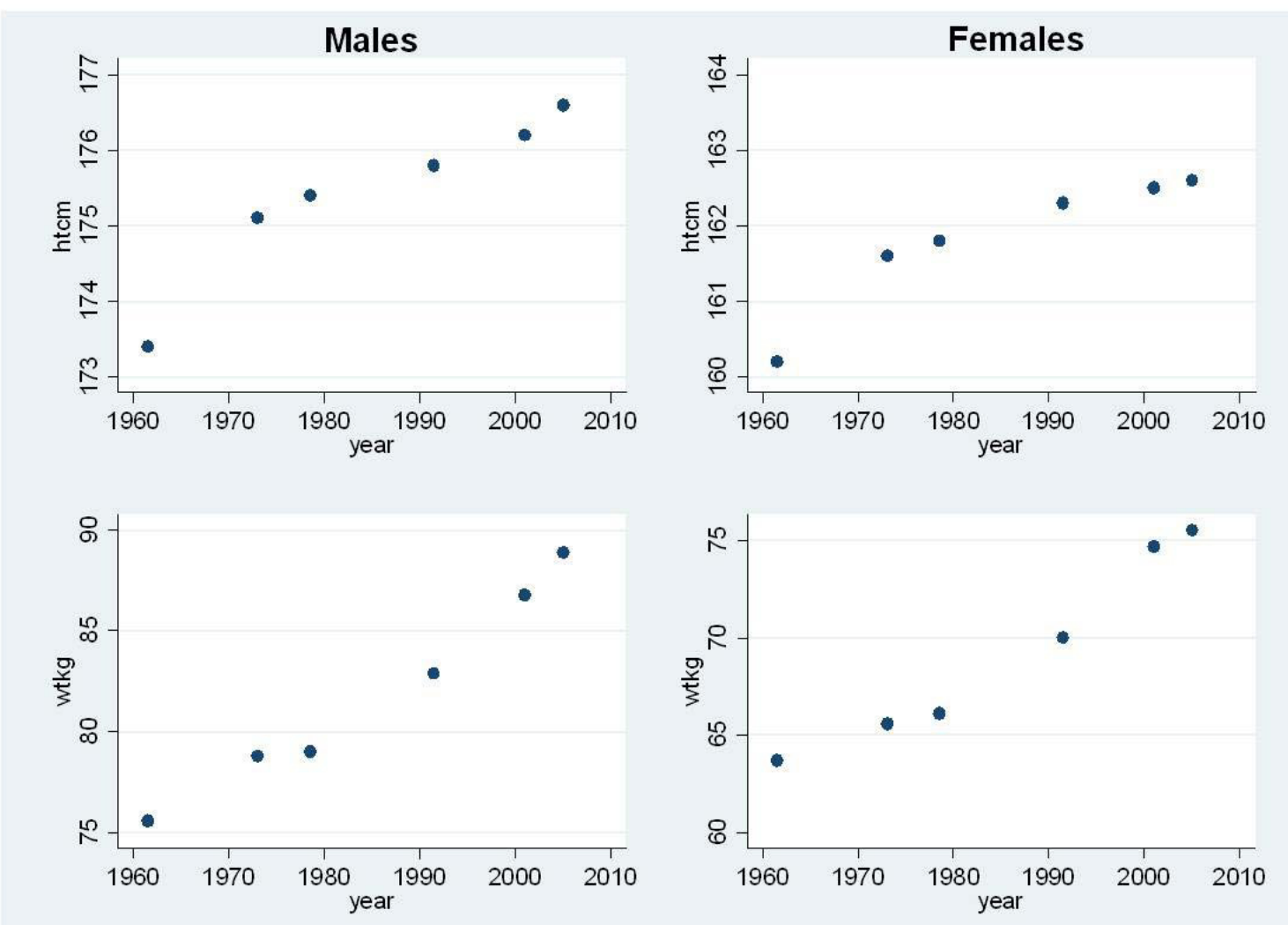

Fig 1. Changes in Mean Stature \& Weight for U.S. Civilians, 20-74 yrs of age: 1962-2006 (Stature and Weight means are taken from Ogden et al [9], McDowell et al [6], and calculated from the NHANES 2003-04 and 2005-06 data releases [7]). 
Table

Prevalence of Obesity (BMI $>30$ ) Among US Adults

\begin{tabular}{|c|c|c|c|c|c|c|c|c|}
\hline & $1960-62$ & 1971-74 & 1976-80 & 1988-94 & 1999-2000 & 2001-02 & 2003-04 & 2005-06 \\
\hline Males & $10.70 \%$ & $12.10 \%$ & $12.70 \%$ & $20.60 \%$ & $27.70 \%$ & $27.80 \%$ & $31.10 \%$ & $33.30 \%$ \\
\hline Females & $15.80 \%$ & $16.60 \%$ & $17.00 \%$ & $25.90 \%$ & $34.00 \%$ & $33.30 \%$ & $33.20 \%$ & $35.30 \%$ \\
\hline
\end{tabular}

*1960- 2000 Prevalence data from Flegal et al [3] based on adults $20-74$ years of age;

2001- 2006 Prevalence data from Ogden et al $[10,11]$ based on adults aged 20 years and older.

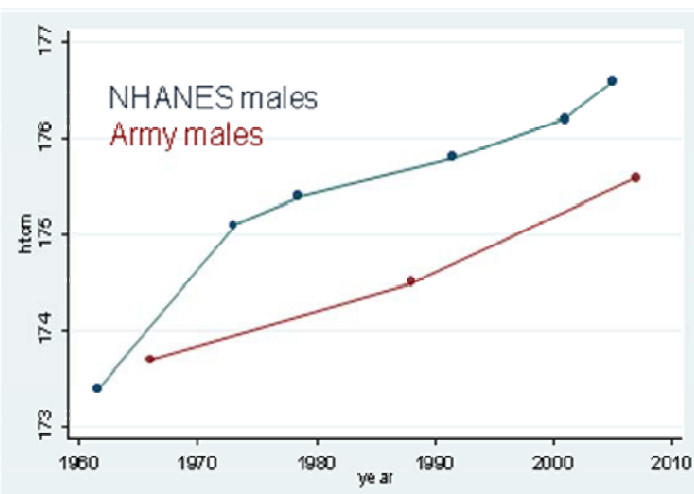

Fig 2. Mean stature for US civilian and US Army males: $1962-$ 2007.

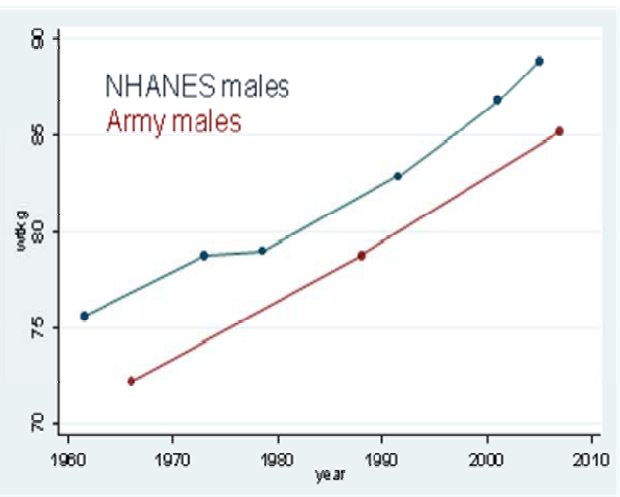

Fig 3. Mean body weight for US civilians and US Army males: $1960-2007$.

Table 2

Prevalence of Obesity (BMI $>30)$ Among US Adult Males and US Civilian Males.

\begin{tabular}{|c|c|c|c|c|c|c|}
\hline & $1960-62$ & 1966 & 1988 & 1988-94 & 2005-06 & 2006-07 \\
\hline US Males & $10.70 \%$ & & & $20.60 \%$ & $33.30 \%$ & \\
\hline Army Males & & $3.60 \%$ & $7.00 \%$ & & & $20.90 \%$ \\
\hline
\end{tabular}

Table 3

Change in Mean Values for Selected Ergonomic Dimensions among US Army Active Duty Males: 1987-1988 vs $2006-2007$ (values in mm).

\begin{tabular}{|c|c|c|c|c|c|}
\hline Males & $\begin{array}{c}1987-1988 \\
N=1774\end{array}$ & $\begin{array}{c}2006-2007 \\
N=1475\end{array}$ & Difference & Probability & Observer Error \\
\hline Stature & 1755.8 & 1760.2 & 4.4 & ns & 5 \\
\hline Sitting Height* & 913.9 & 922.5 & 8.5 & $\mathrm{P}<.001$ & 5.7 \\
\hline Biacromial Breadth & 397 & 409.7 & 12.7 & $\mathrm{P}<.001$ & 7.8 \\
\hline Crotch Height & 837.2 & 836 & -1.2 & ns & 6.8 \\
\hline Knee Height Sitting & 558.8 & 557.9 & -0.9 & ns & 1.8 \\
\hline Weight (kg) & 78.5 & 83.7 & 5.2 & $\mathrm{P}<.001$ & 0.2 \\
\hline Bideltoid Breadth & 491.8 & 499.8 & 8.1 & $\mathrm{P}<.001$ & 7.9 \\
\hline Chest Circumference & 991.4 & 1037.1 & 45.7 & $\mathrm{P}<.001$ & 15 \\
\hline Waist Circumference & 862.4 & 921.9 & 59.5 & $\mathrm{P}<.001$ & 12.4 \\
\hline Buttock Circumference & 983.7 & 1023.3 & 39.7 & $\mathrm{P}<.001$ & 11.7 \\
\hline Hip Breadth Sitting & 366.8 & 371.6 & 4.9 & $\mathrm{P}<.001$ & 6.4 \\
\hline
\end{tabular}

* Table taken from Gordon et al [5]: Anthropometric Change in the US Army: 1987-2007. P values reflect 5\% probability with the Bonferroni adjustment for 11 tests. Observer error refers to the largest expert mean absolute difference in ANSUR trials, reported in Gordon et al [4]. Boldface dimensions have $\mathrm{P}$ values less than 0.001 , and differences larger than the observer error.

physically fit than the civilian pool. Yet, because important ergonomic dimensions are not routinely measured in the civilian surveys, military data are sometimes used in designing office furniture and workstations, as well as in ergonomic standards, such as ANSI/HFES 100 [1].

A solution to the problem of having insufficient dimensions on the population of interest is to esti- 
mate the impact of stature and weight changes on ergonomic parameters using regression equations taken from a military data set. Specifically, we propose to use the 1987-1988 US Army data base (which has sufficiently representative males and fe- males) to calculate regression equations (Table 4) that predict ergonomic dimensions from stature and weight. This data base is ideally suited for this purpose because it is large and demographically diverse.

Table 4

Stature/Weight Regressions* for Workstation Dimensions: 1987-1988 US Army.

\begin{tabular}{|c|c|c|c|c|c|c|c|c|}
\hline & \multicolumn{4}{|c|}{ Males $(n=5057)$} & \multicolumn{4}{|c|}{ Females $(n=3479)$} \\
\hline & $\begin{array}{l}\text { Stature } \\
(\mathrm{mm})\end{array}$ & $\begin{array}{l}\text { Weight } \\
(\mathrm{kg})\end{array}$ & Constant & $\mathrm{R} 2$ & $\begin{array}{l}\text { Stature } \\
(\mathrm{mm})\end{array}$ & $\begin{array}{c}\text { Weight } \\
(\mathrm{kg})\end{array}$ & Constant & $\mathrm{R} 2$ \\
\hline $\begin{array}{l}\text { Abdominal Exten- } \\
\text { sion Depth, Sitting }\end{array}$ & -0.1564 & 2.5624 & 317.5268 & 0.67 & -0.1452 & 3.1675 & 268.4026 & 0.7 \\
\hline $\begin{array}{l}\text { Buttock Knee } \\
\text { Length }\end{array}$ & 0.2936 & 0.7959 & 36.1595 & 0.74 & 0.2483 & 1.3066 & 96.7072 & 0.71 \\
\hline $\begin{array}{l}\text { Buttock Popliteal } \\
\text { Length }\end{array}$ & 0.2868 & 0.3716 & -34.1074 & 0.67 & 0.252 & 0.6708 & 24.8726 & 0.6 \\
\hline Elbow Rest Height & -0.0059 & 0.6841 & 191.3705 & 0.08 & 0.0552 & 0.2545 & 124.0556 & 0.05 \\
\hline Foot Length & 0.1167 & 0.2038 & 47.8473 & 0.55 & 0.1079 & 0.2707 & 49.5019 & 0.5 \\
\hline $\begin{array}{l}\text { Forearm-Forearm } \\
\text { Breadth }\end{array}$ & -0.1875 & 3.5895 & 592.445 & 0.62 & -0.1327 & 3.6779 & 459.5629 & 0.66 \\
\hline $\begin{array}{l}\text { Forearm-Hand } \\
\text { Length }\end{array}$ & 0.2515 & 0.0985 & 32.5818 & 0.62 & 0.2449 & 0.1454 & 28.2582 & 0.59 \\
\hline Hip Breadth, Sitting & -0.0094 & 1.9894 & 228.6642 & 0.74 & -0.0425 & 3.0035 & 273.331 & 0.68 \\
\hline Knee Height, Sitting & 0.3416 & 0.2446 & -61.3784 & 0.81 & 0.3273 & 0.3472 & -44.5135 & 0.78 \\
\hline Popliteal Height & 0.3466 & -0.442 & -141.454 & 0.76 & 0.3506 & -0.7835 & -138.214 & 0.69 \\
\hline Sitting Height & 0.3865 & 0.1764 & 223.871 & 0.61 & 0.4162 & -0.0428 & 184.9214 & 0.64 \\
\hline Thigh Clearance & -0.0455 & 1.0353 & 164.8534 & 0.66 & -0.0391 & 1.1609 & 147.7685 & 0.56 \\
\hline
\end{tabular}

*Regression equations were estimated from the ANSUR research database, with subjects (18-65 yrs) weighted to match Census 2000 age/race distributions. All regression equations were statistically significant at $\mathrm{P}<.0001$. However, coefficients in grey are not significantly different from zero.

By using the stature change and weight change as input values to the regression equation, and ignoring the constant, the equation can estimate the mean change in the civilian ergonomic dimension (Figure 4).

We made these calculations for 12 sample dimensions. Table 5 shows the changes in stature and weight that were used as input values for the regression equations. Table 6 shows the resulting estimates for changes in ergonomic dimensions.

For many of the stature-related dimensions, the change was inconsequential for design. But for many of the weight related dimensions, the changes were substantial. For example, male Forearm-Forearm
Breadth increased by $33.9 \mathrm{~mm}$ (49.0 mm for females) and male Hip Breadth Sitting increased by $20.0 \mathrm{~mm}$ (39.9 $\mathrm{mm}$ for females).

The estimation method described here is based on known changes in the mean values of stature and weight. We applied it to some of the algorithms in ANSI/HFES 100 [1] for workstation design and found similar changes to those design parameters $40.00 \mathrm{~mm}$ in seat pan width, for example. We note that these changes at the mean likely underestimate changes at the tails of the anthropometric distribution, especially at the large end. Design decisions are often based on values at the tails of the anthropometric distribution. 
Eq. 1 Workstation Dimension $($ Time2 $)=a *($ Stature Time2 $)+b^{*}($ Weight Time2 $)+$ constant

Eq. 2 Workstation Dimension $($ Time1 $)=a *($ Stature Time1 $)+b^{*}($ Weight Time1 $)+$ constant

Eq. 3 Workstation $\Delta(T 2-T 1)=a *($ Stature2 - Stature1 $)+b^{*}($ Weight2 - Weight1 $)$

Fig 4. Equations for estimating mean change in ergonomic dimensions.

Table 5

Changes in Stature and Weight: 1987-1988 vs 2005-2006 (values in $\mathrm{kg}$ and $\mathrm{mm}$ ).

\begin{tabular}{|lcccc|}
\hline & \multicolumn{2}{c}{ Males } & \multicolumn{2}{c|}{ Females } \\
& Stature & Weight & Stature & Weight \\
US Army 87-88 & 1755.8 & 78.49 & 1629.4 & 62.01 \\
NHANES 2006 & $\underline{1768.6}$ & $\underline{88.6}$ & $\underline{1628.7}$ & $\underline{75.3}$ \\
Change & 12.8 & 10.11 & -0.7 & 13.29 \\
\hline
\end{tabular}

Table 6

Expected Changes in Workstation Dimensions* (values in $\mathrm{mm}$ ).

\begin{tabular}{|c|c|c|c|}
\hline & Males & Females & Obs Error \\
\hline $\begin{array}{l}\text { Abdominal } \\
\text { Extension } \\
\text { Depth, Sitting }\end{array}$ & 23.9 & 42.2 & 10.4 \\
\hline $\begin{array}{l}\text { Buttock Knee } \\
\text { Length }\end{array}$ & 11.81 & 17.19 & 6.1 \\
\hline $\begin{array}{l}\text { Buttock Popli- } \\
\text { teal Length }\end{array}$ & 7.43 & 8.74 & 7.3 \\
\hline $\begin{array}{l}\text { Elbow Rest } \\
\text { Height }\end{array}$ & 6.84 & 3.34 & 9.8 \\
\hline Foot Length & 3.55 & 3.52 & 3 \\
\hline $\begin{array}{l}\text { Forearm- } \\
\text { Forearm } \\
\text { Breadth }\end{array}$ & 33.89 & 48.97 & 17.3 \\
\hline $\begin{array}{l}\text { Forearm-Hand } \\
\text { Length }\end{array}$ & 4.22 & 1.76 & 3.9 \\
\hline $\begin{array}{l}\text { Hip Breadth, } \\
\text { Sitting }\end{array}$ & 19.99 & 39.95 & 6.4 \\
\hline $\begin{array}{l}\text { Knee Height, } \\
\text { Sitting }\end{array}$ & 6.85 & 4.38 & 1.8 \\
\hline $\begin{array}{l}\text { Popliteal } \\
\text { Height }\end{array}$ & -0.03 & -10.66 & 6.7 \\
\hline Sitting Height & 6.73 & -0.86 & 5.7 \\
\hline $\begin{array}{l}\text { Thigh Clear- } \\
\text { ance }\end{array}$ & 9.88 & 15.46 & 3.3 \\
\hline
\end{tabular}

\section{Conclusion}

US national probability samples have shown little recent increase in stature, while showing substantial increase in weight, and the trend is apparent in US Army data as well. The US lacks a systematic tool for gathering anthropometric data useful for ergonomic design. The changes in probability samples suggest that ergonomic dimensions related to body weight have likely increased substantially in recent years. In the absence of national US ergonomic data, one approach to tracking civilian change in these dimensions is to apply stature/weight regression equations derived from a data base rich in such dimensions, to the civilian population estimates where ergonomic dimensions are generally not available.

This approach gives a rough sense of the average change in dimensions, and is useful for population monitoring. However, this method is not suitable for establishing new design limits, as regression estimates likely underestimate the change at the ends of the distribution, where design limits are often established.

\section{References}

[1] ANSI/HFES 100 (2007). Human Factors Engineering of Computer Workstations. Santa Monica, CA: Human Factors \& Ergonomics Society.

[2] Bradtmiller B, Gordon CC, and Paquette SP (2008) "Anthropometric change in the U.S. Army: Implications for design". Paper presented at the 9th International Congress of Physiological Anthropology, 22-26 August 2008, Delft, the Netherlands.

[3] Flegal, KM, Carroll MD, Ogden CL, Johnson CL (2002) Prevalence and Trends in Obesity Among US Adults, 19992000. JAMA V288:1723-1727.

[4] Gordon CC, Churchill T, Clauser CE, Bradtmiller B, McConville JT, Tebbetts I \& Walker RA (1989) 1988 Anthropometric Survey of U.S. Army Personnel: Methods and Summary Statistics. NATICK/TR-89/044. Natick, Ma: U.S. Army Natick Research, Development, and Engineering Center. (ADA225094). Link to ANSUR database: http://www.dtic.mil/dticasd/docs-a/anthro military. html

[5] Gordon CC, Paquette SP, Bradtmiller B (2008) "Anthropometric Change in the US Army: 1987-2007”. Paper presented at the 33rd Annual Meeting of the Human Biology Association, 9-10 April 2008, Columbus, OH.

[6] McDowell MA, Fryar CD, Ogden CL, Flegal KM (2008) Anthropometric reference data for children and adults: United States, 2003-2006. National health statistics reports; no 10. Hyattsville, MD: National Center for Health Statistics.

[7] National Center for Health Statistics (2009). NHANES (National Health and Nutritional Examination Survey) homepage: http://www.cdc.gov/nchs/nhanes.htm

[8] National Center for Health Statistics (nd). Anthropometric Reference Data, United States, 1988-1994. Available from: http://www.cdc.gov/nchs/ about/major/nhanes/anthropometric measures.htm 
[9] Ogden CL, Fryar CD, Carroll MD, Flegal KM (2004) Mean body weight, height, and body mass index, United States 1960-2002. Advance data from vital and health statistics; no 347. Hyattsville, Maryland: National Center for Health Statistics.

[10] Ogden, C. L., Carroll, M. D., Curtin, L. R., McDowell, M. A., Tabak, C. J., \& Flegal, K. M. (2006). Prevalence of Overweight and Obesity in the United States, 1999-2004 Journal of the American Medical Association, 295, 15491555.

[11] Ogden CL, Carroll MD, McDowell MA, Flegal KM (2007). Obesity among adults in the United States - no change since
2003-2004. NCHS data brief no 1. Hyattsville, MD: National Center for Health Statistics.

[12] Stoudt, HW, Damon, A, McFarland, R \& Roberts, J (1965). Weight, Height, and Selected Body Dimensions of Adults, United States, 1960-62. Vital and Health Statistics, Series 11, Number 8. Hyattsville, MD: National Center for Health Statistics.

[13] White RM \& Churchill E (1971) The body size of soldiers: U.S. Army anthropometry -- 1966. Technical Report 72-51 CE, U.S. Army Natick Laboratories, Natick, MA. (AD743528) 